Article

\title{
Livelihood Vulnerability and Adaptation Capacity of Rice Farmers under Climate Change and Environmental Pressure on the Vietnam Mekong Delta Floodplains
}

\author{
Dung Duc Tran ${ }^{1}{ }^{5}$, Chau Nguyen Xuan Quang ${ }^{2, *} \mathbb{\infty}$, Pham Duy Tien ${ }^{3}$, Pham Gia Tran ${ }^{4}$, \\ Pham Kim Long ${ }^{5}$, Ho Van Hoa ${ }^{2}$, , Ngo Ngoc Hoang Giang ${ }^{2}$ and Le Thi Thu Ha ${ }^{6}$ \\ 1 Center of Water Management and Climate Change, Institute for Environment and Resources, \\ Vietnam National University-Ho Chi Minh City (VNU-HCM), Ho Chi Minh City 700000, Vietnam; \\ dungtranducvn@yahoo.com \\ 2 Department of Hydrology and Water Resources, Institute for Environment and Resources, \\ Vietnam National University-Ho Chi Minh City (VNU-HCM), Ho Chi Minh City 700000, Vietnam; \\ harryhoa@gmail.com (H.V.H.); nnhgiang.env@gmail.com (N.N.H.G.) \\ 3 Faculty of Agriculture and Natural Resources, An Giang University, VNU-HCM, 18 Ung Van Khiem, \\ Long Xuyen City, An Giang 880000, Vietnam; pdtien.agu@gmail.com \\ 4 Department of Population and Social Geography, Faculty of Geography, University of Social Sciences and \\ Humanities, Viet Nam National University, Ho Chi Minh City 700000, Vietnam; \\ phamgiatran@hcmussh.edu.vn \\ 5 Tra Vinh University, Tra Vinh 940000, Vietnam; kimlongpham@gmail.com \\ 6 Southern Institute of Ecology, Vietnam Academy of Science and Technology, 1D, TL29 Street, District 12, \\ Ho Chi Minh City 700000, Vietnam; lttha@sie.vast.vn \\ * Correspondence: cnxquang@gmail.com
}

Received: 23 October 2020; Accepted: 20 November 2020; Published: 22 November 2020

\begin{abstract}
Agricultural production is the primary source of income and food security for rural households in many deltas of the world. However, the sustainability of farm livelihoods is under threat, due to the impacts of climate change and environmental pressure, including shifting hydrological regimes, droughts, water pollution, land subsidence and riverbank erosion. This study evaluated the livelihood sustainability and vulnerability of triple rice farmers on the floodplains of the Vietnam Mekong Delta (VMD). We focused on the perceptions of rice farmers, based on a survey of 300 farmers. Increasing temperatures, drought, water pollution and sediment shortages were the four factors considered by farmers to have the most impact on their agricultural livelihoods. We analyzed farmers' capacity to sustain their livelihoods and adapt to the changing environment. Results show relatively low vulnerability of rice farmers overall, though many of those surveyed reported very low incomes from rice production. Factors of most concern to farmers were rising temperatures and more frequent droughts. Farmers were already taking steps to adapt, for example, increasing production inputs and investing more labor time, as well as switching production methods. Yet, our findings suggest that policymakers and scientists have a role to play in developing more sustainable adaptation paths. The research clarifies the livelihood vulnerability of triple rice farmers on the VMD floodplains, while more generally contributing to the body of literature on farming and climate change and environmental pressure.
\end{abstract}

Keywords: rice; vulnerability; sustainability; Mekong; climate change; environmental pressure 


\section{Introduction}

In many deltas of the world, rural populations are highly dependent on agriculture [1-3]. However, farmers often do not earn enough income for a sustainable livelihood [4-7]. In light of global food crises, agricultural intensification has emerged over the decades as a key strategy to meet growing food demand. However, intensification of agriculture can lead to environmental damage. The concept of "livelihood sustainability" concerns the ability to cope with and recover from stresses and shocks such as those caused by climate change and environmental pressure [8-11]. Indeed, the world has seen a dramatic increase in stresses linked to the climate and environment, such as land and water pollution, land subsidence and riverbank erosion. These have exacerbated the tenuousness of the livelihoods of many rural populations $[2,12,13]$. The impacts of environmental pressure merit investigation, and adaptive alternatives should be urgently explored to achieve more diversified agricultural production systems that are more resilient, less vulnerable and more environmentally sustainable $[2,14]$.

Many studies have assessed the vulnerability and sustainability of livelihoods under the impacts of climate change and environmental pressure [15-18]. Zhao et al. [16] evaluated the livelihood sustainability of towns in Shenzha, China under various disaster contexts using a sustainable framework. The results showed a great disparity of sustainable livelihoods among the three vulnerability groups. In another study, Su et al. [17] applied a mixed method that integrated livelihood capital index (LCI) to analyze the livelihood capital and strategy of different household types in response to seasonal fluctuations in tourism in Nanning, Guangxi of China. Furthermore, the study of Liu et al. [18] elaborated the influence of farm household livelihood assets on livelihood strategies in Zunyi City of China, then evaluated different farm household livelihood assets in coping with risks and shocks. We found that livelihood capital index and livelihood vulnerability index (LCI and LVI) have been used as one of the appropriated methods to evaluate livelihood sustainability and vulnerability under various changes such as climate and environmental pressure.

The Vietnam Mekong Delta (VMD) is extremely vulnerable to the effects of climate change [12,19-21]. The impacts of climate change-primarily, increasing temperatures and more frequent rainfall—paired with socioeconomic developments, will likely significantly affect the VMD's hydrological regime. Temperatures across the delta rose by $1.3-1.4^{\circ} \mathrm{C}$ between 1986 and 2014, and could rise another $1.9-3.5^{\circ} \mathrm{C}$ by 2099 [22]. Additionally, recent climate change impact assessments found that large-scale, high dike structures have substantially increased the risk of flooding in the delta over the coming decades $[4,21,23]$. Simultaneously, hydropower production is rapidly expanding in the Mekong region, with an ever-increasing number of hydropower reservoirs being planned and under construction in the delta's upstream reaches [24,25]. Reservoir operations have raised concerns about flow regime modifications [24,26,27], and an array of other secondary, yet critical, impacts on the environment [28], sediment dynamics [29,30], fishery resources [19], riverbank erosion [4,31] and water pollution from intensified agricultural production [5,32].

The majority of small-scale VMD farmers consider rice their primary source of income [33]. Following the national renovation policy in 1986, rice production was intensified, and areas under double and triple rice cropping were progressively expanded with greater privatization and commercialization of agriculture from the early 1990s [34]. Across the upper delta floodplains, communities built dikes to protect their fields during the flood season, thus making a third rice crop viable. This enabled many farmers to switch from two to three rice crops annually. Water management infrastructures were built throughout the 1990s and into the 2000s, bringing continued expansion of intensive double and triple rice cropping, particularly after 2004 [35]. Yet, stakeholders are increasingly questioning the trade-offs between dike construction for triple rice production and farmers' livelihood sustainability. A particular concern is whether the strategy of rice intensification is in fact a sustainable livelihood option for delta farmers in the long term.

An Giang, one of the provinces of the VMD floodplains, is an example of the pattern of rice intensification from double to triple cropping [4]. Since 2002, the government has upgraded dike 
systems here, increasing the number of high dikes to facilitate triple rice production. Large parts of the upper and central deltas are now protected by these dikes [35]. Since the initiation of the rice intensification policy, up to 2015, An Giang's area under triple rice cultivation grew from 2591 ha to 150,000 ha [36], remaining at that level through 2019, according to [37]. The expansion of triple rice production has had substantial social and environmental consequences in An Giang province [6,38]. First, labor demand has been on the decline for many years, due to the mechanization of rice production. Second, in flood-prone zones, previously open-access fisheries are closed off by high dikes during the flood season, eliminating a source of income and subsistence for poor and landless inhabitants [38]. Third, continuous cultivation of three rice crops per year has had harmful effects on the environment, particularly in regard to soil fertility [38]. Lands continually cropped to rice do not benefit from an influx of fertile sediment brought by floodwaters; the consequence is exhausted soils with diminishing returns [6]. Many triple rice farmers are indeed seeing diminishing returns, leading to concerns about livelihood sustainability across the province.

Little is known about rice farmers' own perspectives on the influences of climate change and environmental pressure on their farming operations and the future. Particularly, vulnerability assessments and information about changes in livelihood sustainability over the past five years are scarce. The current study sought to fill this gap. Using a sustainable livelihood framework [39], we examined five types of capital—social, financial, human, natural and physical—and two aspects of climate change, according to the definition of the Intergovernmental Panel on Climate Change (IPCC). Our aim was to assess the vulnerability of triple rice farmers' livelihoods under the influence of climate change and environmental pressure. We hypothesized that triple rice farmers' livelihoods were not sustainable in economic and environmental terms. Moreover, we expected many farmers to have taken steps to adapt their farming operations in the face of climate change and environmental pressure. To gain information from farmers, we developed a structured questionnaire which we then used to interview 300 rice farmers in three districts of An Giang province of the VMD.

\section{Study Area}

An Giang province has an area of $3536.7 \mathrm{~km}^{2}$ and ranks fourth in terms of size among the VMD's 13 provinces (Figure 1). It is bordered to the east by Dong Thap province, and to the north and northwest by Kandal and Takeo provinces of Cambodia with a nearly $104 \mathrm{~km}$-long border. To the southwest, An Giang borders on Kien Giang province, and to the south it borders Can Tho city.

The province is located in the delta's upstream floodplain, giving it the advantages of abundant surface water and fertile soils, thanks to the alluvium conveyed by floodwaters. Besides, the state has long invested in irrigation systems and flood control works here, making the province a suitable location for agricultural development. In the past three decades, the province has emphasized advanced production methods, especially intensified rice production, aquaculture and fruit tree planting. This has led to rapid socio-economic development. The rice area of the province in 2018 was some 623,000 ha, but it accounted for $16 \%$ of the annual rice production of the VMD and $8.8 \%$ of Vietnam's rice production [37]. Besides rice cultivation, the growing fish industry, mainly pangasius and catfish, have made the province a center for catfish export and the freshwater fishing industry [40].

However, An Giang faces many obstacles in the context of climate change. Temperatures are rising and extreme flooding is increasingly frequent, as are droughts, riverbank landslides, saltwater intrusion and storms. In addition, development of hydroelectric dams in the upper reaches of the delta have modified flood regimes and sedimentation loads [19]. In the 2011-2016 period, economic losses due to natural disasters here amounted to some USD 64 million (VND 1463 billion). Damages due to flooding, thunderstorms and storms totaled USD 42 million (VND 932 billion), and landslides caused USD 18 million in damages (VND 407 billion). In 2018 alone, economic losses due to natural disasters were some USD 9 million (VND 198 billion) [37]. Before large-scale dam construction, most of An Giang province was subject to a natural flooding regime. Fields were drained so floodwaters could enter, flushing alum and depositing fertile sediment on fields, also bringing in wild fish to 
refresh aquatic resources in ponds and lakes. After the extreme floods of 2000 destroyed property and crops, strongly impacting the lives of delta residents, high dikes were built for protection as well as to provide footing for main roads. Construction of high dikes also allowed for cultivation of three rice crops annually [41]. Simultaneously, many reservoirs and dams were put into operation to store water upstream. Severe flooding has thus been rare in recent years. These changes have introduced a new setting for the province's socio-economic development and rural farmers' livelihoods.

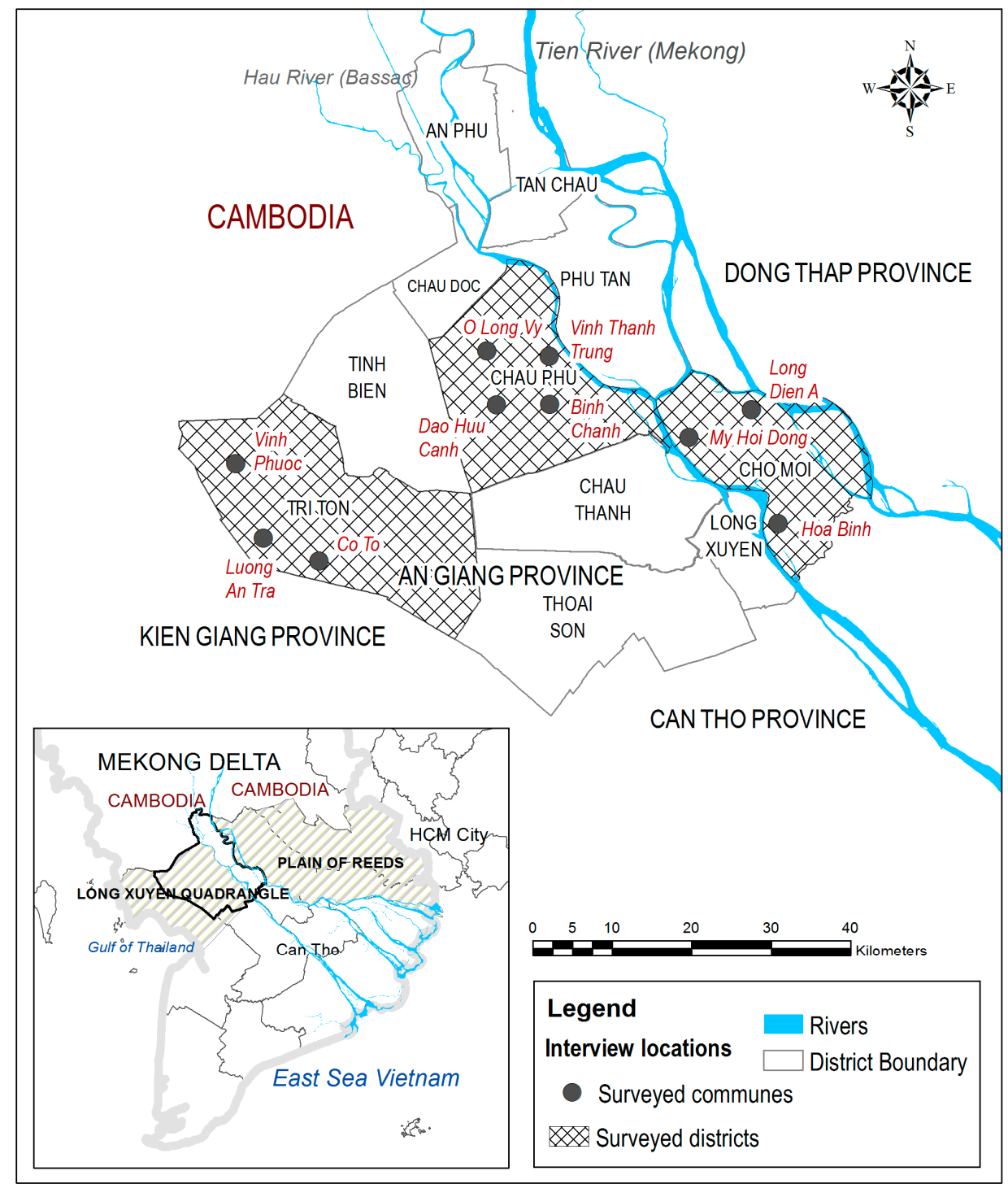

Figure 1. Map showing An Giang province and surroundings, with the study districts shaded and locations of the 10 survey communes.

\section{Methods}

\subsection{Data Collection}

Data were collected by means of a survey conducted in July and August 2020 in three districts of An Giang province: Chau Phu, Cho Moi and Tri Ton (Figure 1). We interviewed 300 farmers from 10 communes, targeting 30 farmers in each commune, including O Long Vi, Vinh Thanh Trung, Binh Chanh, Dao Huu Canh in Chau Phu district; Long Dien A, My Hoi Dong, and Hoa Binh in Cho Moi district; and Vinh Phuoc, Co To, and Luong An Tra in Tri Ton district. The selected study districts represent two types of location: nearby and far away from the main rivers. Triple rice cultivation was 
the dominant production system in all areas. Chau Phu and Cho Moi were located close to the main rivers, while Tri Ton was farther away from the rivers, on the border with Kien Giang province to the south. The populations are 246,402 for Chau Phu, 347,481 for Cho Moi, and 134,713 for Tri Ton [42].

The interviews were structured and followed a predesigned questionnaire. The questionnaire had five sections: (i) basic information about the farm and farm household head (gender, age, education level, health status and land area); (ii) perceptions of the impacts of climate change and environmental pressure on their rice cultivation; (iii) measures taken in farming activities to adapt to the changing climate and environmental pressure; (iv) ability of the farm household to maintain current crop production; and (v) changes in production practices and strategies now and in the future. Before the main survey was carried out, we pretested the questionnaire, making adjustments to ensure that all questions were understandable and elicited relevant responses. The surveyed farmers were household heads currently active in agricultural activities in the study districts. The interviewing time for each farmer was about $60 \mathrm{~min}$.

\subsection{Sampling Methods}

Simple random sampling was used to choose the farmers to be interviewed. First, we requested the help of local officials in each commune to better understand general characteristics of local agricultural systems and farmers' livelihoods. They also recommended places to visit and contacts in each commune. In the communes, we randomly chose farmers who had been cultivating triple-crop rice for at least a couple of years. The farmers had to be a household head. In some cases, we conducted the interviews during farmers' work on the rice fields.

\subsection{Livelihood Vulnerability Assessment}

\subsubsection{Livelihood Vulnerability Index (LVI) Analysis}

To assess the vulnerability of farming households to climate change and environmental pressure, we used the livelihood vulnerability index (LVI) approach, initially developed by Hahn et al. [15]. Several studies have applied this method to assess livelihood vulnerability [1,41,42]. LVI usually employs seven key components to assess vulnerability: socio-demographic profile, health, social networks, food, water, livelihood strategy, and natural disasters and climate variability $[1,43]$.

In this study, we classified the components under five different livelihood capitals in the sustainable livelihood framework established by the Department for International Development (DFID) in the UK [39]. Therefore, seven main components were derived to capture farm households' positions in regard to the five livelihood capitals, i.e., social, financial, human, natural and physical, and in relation to the two aspects representing climate change and environmental pressure in this study, i.e., livelihood strategy, and natural disasters and climate variability (please see Table A1 in the Appendix A). Human and physical components included knowledge and skills, experience and labor resource, land status, and equipment for housing and agricultural production. Social and natural capital components covered socio-demographic characteristics, social network, and media. Financial capital component related mostly to farmers' loans and income. Livelihood strategy component referred mainly to farmers' adaptability and experience in dealing with livelihood changes. The natural disaster and climate change components related mainly to temperature, rainfall, drought, riverbank erosion, water pollution and soil fertility. In total, we derived forty (40) subcomponents. All main components and subcomponents were selected based on the literature, authors' knowledge of the study area and culture, and information gained in consultations with experts. Data on the subcomponents were elicited through questions on the questionnaire.

The LVI approach measures each of the subcomponents on a different scale, meaning they must first be standardized as an index. This was done using Equation (1) [15]:

$$
\operatorname{Index}_{S_{d}}=\frac{S_{d}-S_{\min }}{S_{\max }-S_{\min }}
$$


where $S_{d}$ is the original subcomponent for district $d$, i.e., Chau Phu, Tri Ton or Cho Moi; and $S_{\text {max }}$ and $S_{\min }$ are the minimum and maximum values, respectively, for each subcomponent. After the subcomponents were standardized, their averages were computed using Equation (2):

$$
M_{d}=\frac{\sum_{i=1}^{n} I_{\text {Index }} \text { S }_{d_{i}}}{n}
$$

where $M_{d}$ is one of the seven key components in district $d$ or one of the indexes for a dimension of vulnerability; Index $S_{d_{i}}$ is the indicator value of the $i$ th component/indicator, and $n$ is the number of subcomponents in each main component. After all values of the key components were determined, the LVI was calculated using Equation (3):

$$
L V I_{d}=\frac{\sum_{i=1}^{7} w_{M_{i}} M_{d_{i}}}{\sum_{i=1}^{7} w_{M_{i}}}
$$

where $L V I_{d}$ is the livelihood vulnerability index for the susceptibility to climate change or environmental pressure in district $d$ (Chau Phu, Tri Ton or Cho Moi), corresponding to the weighted average of the key components. The weight of each key component, $W_{M i}$, was specified by the number of subcomponents contributing to the main components. LVI values ranged from 0 (least vulnerable) to 1 (most vulnerable).

\subsubsection{Calculating the LVI-IPCC}

The definition characterizes vulnerability in terms of three categories referred from Haln et al. [15]: adaptive capacity, sensitivity and exposure [44]. In other words, the LVI-IPCC is computed by grouping the seven main components into three categories, namely, adaptive capacity, sensitivity and exposure $[1,45]$. Adaptive capacity is determined by socio-demographic profile, social networks and livelihood strategies. Sensitivity refers to knowledge and skills, natural resources, and finances; while exposure is measured by effects of natural disasters and impacts of climate change. All these subcomponents based on the seven main components or ten components are presented in Table A1 in the Appendix A. Equation (4) was used to compute the combined contributing factors of the main components:

$$
C F_{d}=\frac{\sum_{i=1}^{n} w_{M_{i}} M_{d_{i}}}{\sum_{i=1}^{n} w_{M_{i}}}
$$

where $C F_{d}$ is the contributing factor; $M_{d i}$ is a key factor for district $d$ (Cho Moi, Tri Ton or Chau Phu), indexed by $I ; W_{M i}$ is the weight of each main component; and $n$ is number of main components in each contributing factor. Once exposure, sensitivity, and adaptive capacity are computed for each area $\mathrm{d}$, the combination of these three contributing factors is calculated using the following equation:

$$
\text { LVI-IPCC }=(\text { Exposure }- \text { Adaptive Capacity }) \times \text { Sensitivity }
$$

LVI-IPCC values range from -1 (least vulnerable) to 1 (most vulnerable).

\section{Results and Discussion}

\subsection{Farm and Farmer Characteristics}

Table 1 presents the characteristics of the rice farmers interviewed. Most household heads had a relatively high mean age, over 50, and substantial experience in rice production, about 20 years. However, most household heads (80\%) had little formal education, with $45 \%$ having less than a primary school education and 35\% under the secondary school level. There was a dominance of male household heads (94\%), confirming findings from previous studies [3,5,6]. Households averaged five members, 
with two or three farm laborers each (2.4 average). The father and mother were usually responsible for rice cultivation in their families.

Table 1. Farm and farmer characteristics in three districts of An Giang province, $n=300$.

\begin{tabular}{|c|c|c|c|c|}
\hline Characteristics & Chau Phu $(n=120)$ & Tri Ton $(n=90)$ & Cho Moi $(n=90)$ & All $(n=300)$ \\
\hline \multicolumn{5}{|l|}{ Farm household head } \\
\hline Age (years) & 51.5 & 47.7 & 51.8 & 50.4 \\
\hline $\begin{array}{l}\text { Experience in rice } \\
\text { production (years) }\end{array}$ & 21.2 & 18.3 & 23.3 & 20.9 \\
\hline \multicolumn{5}{|l|}{ Education (\% completed) } \\
\hline Primary & 48 & 52 & 36 & 45 \\
\hline Secondary & 34 & 27 & 43 & 35 \\
\hline Tertiary & 16 & 21 & 16 & 17 \\
\hline Higher education & 3 & 0 & 6 & 3 \\
\hline \multicolumn{5}{|l|}{ Gender $(\%)$} \\
\hline Male & 93 & 93 & 94 & 94 \\
\hline Female & 7 & 7 & 6 & 6 \\
\hline $\begin{array}{c}\text { Number of household } \\
\text { members }\end{array}$ & 4.9 & 4.5 & 4.5 & 4.6 \\
\hline Farm characteristics & 0 & 0 & 0 & 0 \\
\hline Farm size (ha) & 2.3 & 4.3 & 1.9 & 2.8 \\
\hline Farm laborers & 2.3 & 2.4 & 2.6 & 2.4 \\
\hline \multicolumn{5}{|l|}{ Mean yield (ton/ha) } \\
\hline $\begin{array}{c}\text { Winter-Spring } \\
\text { (December-March) }\end{array}$ & 8.1 & 7.9 & 7.4 & 7.8 \\
\hline $\begin{array}{l}\text { Summer-Autumn * } \\
\text { (April-July) }\end{array}$ & 7.0 & 6.4 & 6.3 & 6.6 \\
\hline $\begin{array}{l}\text { Autumn-Winter }{ }^{* *} \\
\text { (July-December) }\end{array}$ & 7.2 & 6.5 & 6.5 & 6.7 \\
\hline \multicolumn{5}{|l|}{ Selling price (USD/ton) } \\
\hline $\begin{array}{c}\text { Winter-Spring } \\
\text { (December-March) }\end{array}$ & 241 & 244 & 236 & 240 \\
\hline $\begin{array}{l}\text { Summer-Autumn* } \\
\text { (April-July) }\end{array}$ & 232 & 242 & 225 & 233 \\
\hline $\begin{array}{c}\text { Autumn-Winter }{ }^{* *} \\
\text { (July-December) }\end{array}$ & 243 & 240 & 232 & 238 \\
\hline $\begin{array}{l}\text { Annual mean profit/ha } \\
\qquad\left(10^{6} \mathrm{VND}\right)\end{array}$ & 46 & 40 & 31 & 39 \\
\hline $\begin{array}{l}\text { Annual mean profit/ha } \\
\text { (USD) }\end{array}$ & 2074 & 1813 & 1403 & 1763 \\
\hline
\end{tabular}

Note: We used the 2020 exchange rate, by which USD $1=$ VND 22,300. ${ }^{*}$ These calculations use data from 87 households in Chau Phu, 85 households in Tri Ton and 89 households in Cho Moi as, respectively, 33, 5 and 1 households in these districts reported having lost their rice crop in this season due to drought, extreme rainfall or other circumstances. ** These calculations use data from 99 households in Chau Phu, 81 households in Tri Ton and 89 households in Cho Moi as, respectively, 21, 9 and 1 households in these districts reported having lost their rice crop in this season due to drought, extreme rainfall or other circumstances.

Regarding farm characteristics, of primary interest were farm size, seasonal rice yield and selling price, and annual profit from rice production. Farm sizes averaged 2.8 ha. Farms were larger, 
on average, in Tri Ton (4.3 ha) than in Chau Phu and Cho Moi (respectively, 1.9 ha and 2.3 ha). This reflects the situation in much of rural VMD, as farms tend to be smaller nearer to cities [46]. Regarding rice yields, the highest yields were reported for the winter-spring rice crop, averaging 7.8 ton/ha. Yields in the summer-autumn season averaged 6.6 ton/ha and autumn-winter yields averaged 6.7 ton/ha. The highest yields were reported in the winter-spring season in Chau Phu (8.1 ton/ha), when yields were 7.9 and 7.4 ton/ha, respectively, in Tri Ton and Cho Moi. The average selling price of the winter-spring rice crop was also highest, at USD 240/ton, compared to USD 233 and USD 238/ton in the summer-autumn and autumn-winter seasons, respectively. Mean annual profit from rice production was USD 1763. Farmers in Chau Phu district earned the highest annual profit (USD 2074), followed by their counterparts in Tri Ton (USD 1813) and Cho Moi (USD 1403). The profit from the triple rice production is relatively low compared to other diversified crop models such as double rice plus vegetable or aquaculture which were found by previous studies [3,47]. In addition, the yield loss of a number of triple rice farmers due to the drought and extreme rainfall in the two seasons of summer-autumn and autumn-winter should be taken into account by investigating suitable measures such as water saving irrigation, changes in crop patterns and improved rice varieties.

\subsection{Vulnerability Assessment Using LVI and LVI-IPCC}

The vulnerability spider diagram (Figure 2) shows a range between 0 (least vulnerable) and 0.6 (most vulnerable). LVI results indicate that, in general, farmers in Tri Ton were more vulnerable (0.383) than those in Cho Moi (0.376) and Chau Phu (0.356). We found overall low vulnerability among farmers in the three districts with regard to the five capitals (social, financial, human, natural and physical) (Table 2). LVI values ranged from 0.238 to 0.331 for human capital, from 0.279 to 0.287 for social capital, from 0.371 to 0.383 for physical capital, from 0.210 to 0.288 for financial capital, and from 0.006 to 0.196 for natural capital. Farmers were found to be most vulnerable to the effects of climate change and environmental pressure on the component livelihood strategy (0.564 to 0.547$)$ and on the component natural disasters and climate change (0.406 to 0.461). Although vulnerability patterns were similar for the three districts, regarding human capital, farmers in Chau Phu were found to be less vulnerable than those in the other two districts $(0.238$ compared to 0.331 and 0.289$)$. On natural capital, we found farmers in Cho Moi to be more vulnerable than those in Chau Phu and Tri Ton. Table A1 in the Appendix A presents the LVI calculations in more detail.

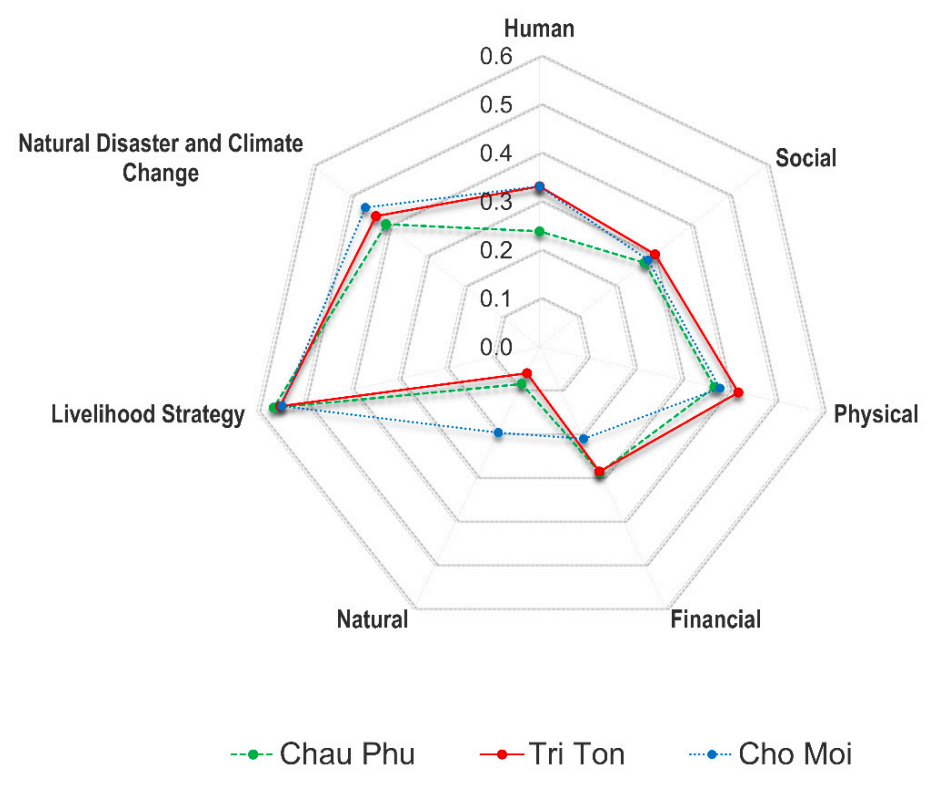

Figure 2. Vulnerability spider diagram of livelihood vulnerability index (LVI) key components for the three study districts of An Giang province. 
Table 2. LVI key components in the three study districts of An Giang province.

\begin{tabular}{cccc}
\hline Key Components & Chau Phu & Tri Ton & Cho Moi \\
\hline Human & 0.238 & 0.331 & 0.331 \\
Social & 0.278 & 0.306 & 0.287 \\
Physical & 0.371 & 0.422 & 0.383 \\
Financial & 0.288 & 0.285 & 0.210 \\
Natural & 0.085 & 0.060 & 0.196 \\
Livelihood strategy & 0.564 & 0.550 & 0.547 \\
Natural disaster and climate change & 0.406 & 0.433 & 0.461 \\
\hline LVI (overall average) & $\mathbf{0 . 3 5 6}$ & $\mathbf{0 . 3 8 3}$ & $\mathbf{0 . 3 7 6}$ \\
\hline
\end{tabular}

Our findings indicate the need for farmers in the study area to shift away from a triple rice monocrop towards alternative production strategies, such as crop diversification, to enhance the sustainability of their livelihoods and to reduce their vulnerability to the impacts of climate change and environmental pressure. These findings echo those of earlier works [14,46-48]. However, adaptation efforts by farmers require dedicated support from local government and the scientific establishment [6]. Though we found relatively low vulnerability regarding nature capital, this does not mean that natural values are already sufficiently preserved. Indeed, we recommend targeted efforts to ensure that natural resources are exploited sustainably.

Regarding the LVI-IPCC calculations, overall averages for Chau Phu, Tri Ton and Cho Moi were 0.006, 0.090 and 0.017, respectively (Figure 3 and Table 3). This implies that overall, in terms of climate change and natural disaster (environmental pressure), Cho Moi was more vulnerable than Chau Phu and Tri Ton.

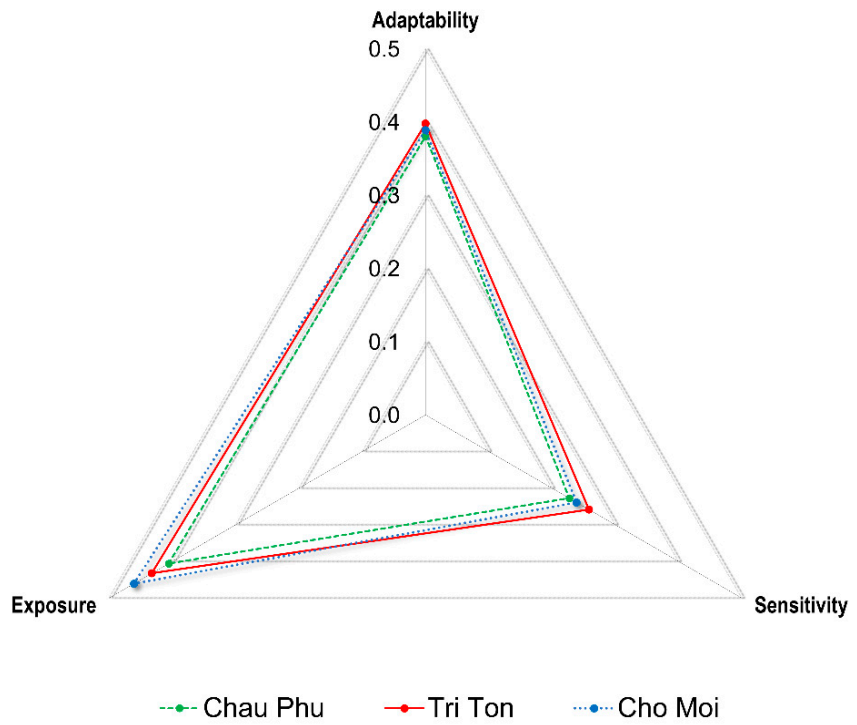

Figure 3. Vulnerability triangle of LVI-Intergovernmental Panel on Climate Change (IPCC) contributing factors for the three study districts in An Giang province.

We computed LVI-IPCC values by grouping the seven key components into three categories, namely, exposure, sensitivity and adaptive capacity. The vulnerability triangle indicates that households in Cho Moi and Tri Ton were more exposed and sensitive to climate change and environmental pressure than those in Chau Phu, taking into consideration the health, knowledge and skills, and land status of the households in the districts. Farmers in Cho Moi and Tri Ton were also more vulnerable in terms of adaptive capacity, taking into consideration their socio-demographic profile, social networks and livelihood status. The low LVI-IPCC values found for sensitivity $(0.227$ to 0.258$)$ indicate that households in the study districts had relatively good health, knowledge and skills, and land status. 
Table 3. Key components of the LVI-IPCC for the three study districts in An Giang province.

\begin{tabular}{cccc}
\hline Components & Chau Phu & Tri Ton & Cho Moi \\
\hline Adaptability & 0.381 & 0.398 & 0.389 \\
Sensitivity & 0.227 & 0.258 & 0.239 \\
Exposure & 0.406 & 0.433 & 0.461 \\
\hline LVI-IPCC (overall average) & $\mathbf{0 . 0 0 6}$ & $\mathbf{0 . 0 0 9}$ & $\mathbf{0 . 0 1 7}$ \\
\hline
\end{tabular}

\subsection{Farmers' Perceptions of Climate Change and Environmental Pressure}

Figure 4 presents farmers' perceptions of the impacts of climate change and environmental pressure, specifically in regard to temperatures, drought, groundwater conditions, water pollution, riverbank erosion and sediment supply. Most farmers (89\%) perceived increasing temperatures over the past five years (Figure 4a). Some 58\% noted diminished sediment supply, while 53\% and 40\%, respectively, perceived worsening water pollution and more frequent droughts. Regarding future changes, farmers expected a similar pattern of change to continue (Figure 4b). However, most felt that the impacts of climate change and environmental pressure would accelerate. Some $93 \%$ expected temperature increases to accelerate, $72 \%$ expected greater water pollution, $58 \%$ expected increasing sediment shortages, and $53 \%$ expected more frequent droughts. Notably, groundwater conditions and riverbank erosion were not perceived as concerns, either in the past five years or looking towards the future.

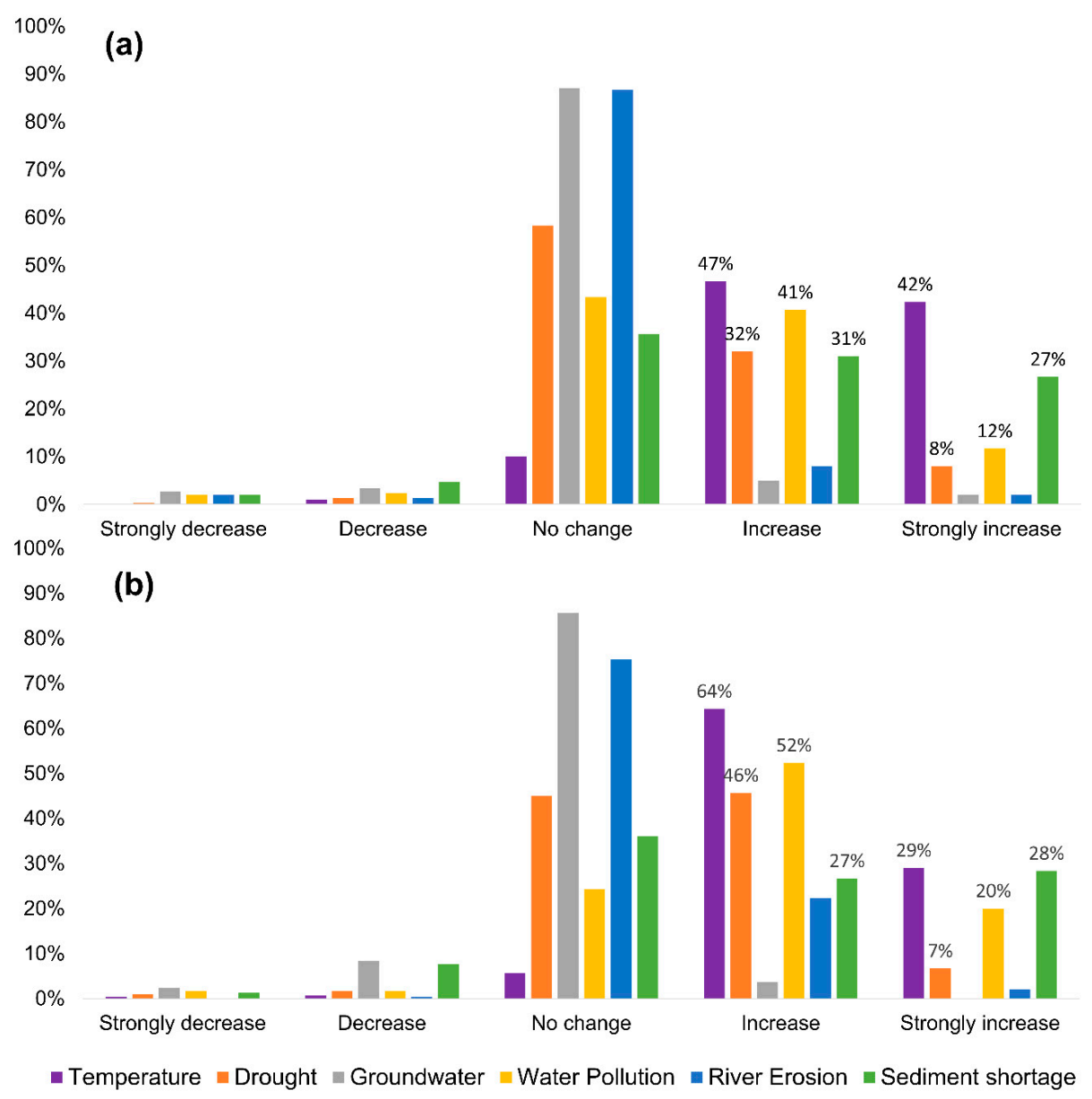

Figure 4. Farmers' perceptions regarding the past five years (a) and future (b) impacts of climate change and environmental pressure. 
Figure 5 shows farmers' perceptions of the impacts of climate change and environmental pressure on their livelihoods. The impact patterns here confirm the findings presented in Figure 4. Temperature $(96 \%)$ and drought $(69 \%)$ were considered to have the greatest impact on farmer livelihoods. Particularly, farmers were worried about low flows in the main rivers of the VMD in recent years, as also documented in $[49,50]$. Many farmers also noted worsening water pollution (63\%) and sediment shortages $(56 \%)$ as hindering their agricultural activities and livelihoods. Though reported by farmers as having relatively less impact than the four other factors, riverbank erosion (41\%) and groundwater conditions $(27 \%)$ cannot be disregarded as potentially having substantial impacts on farmers' future livelihoods.

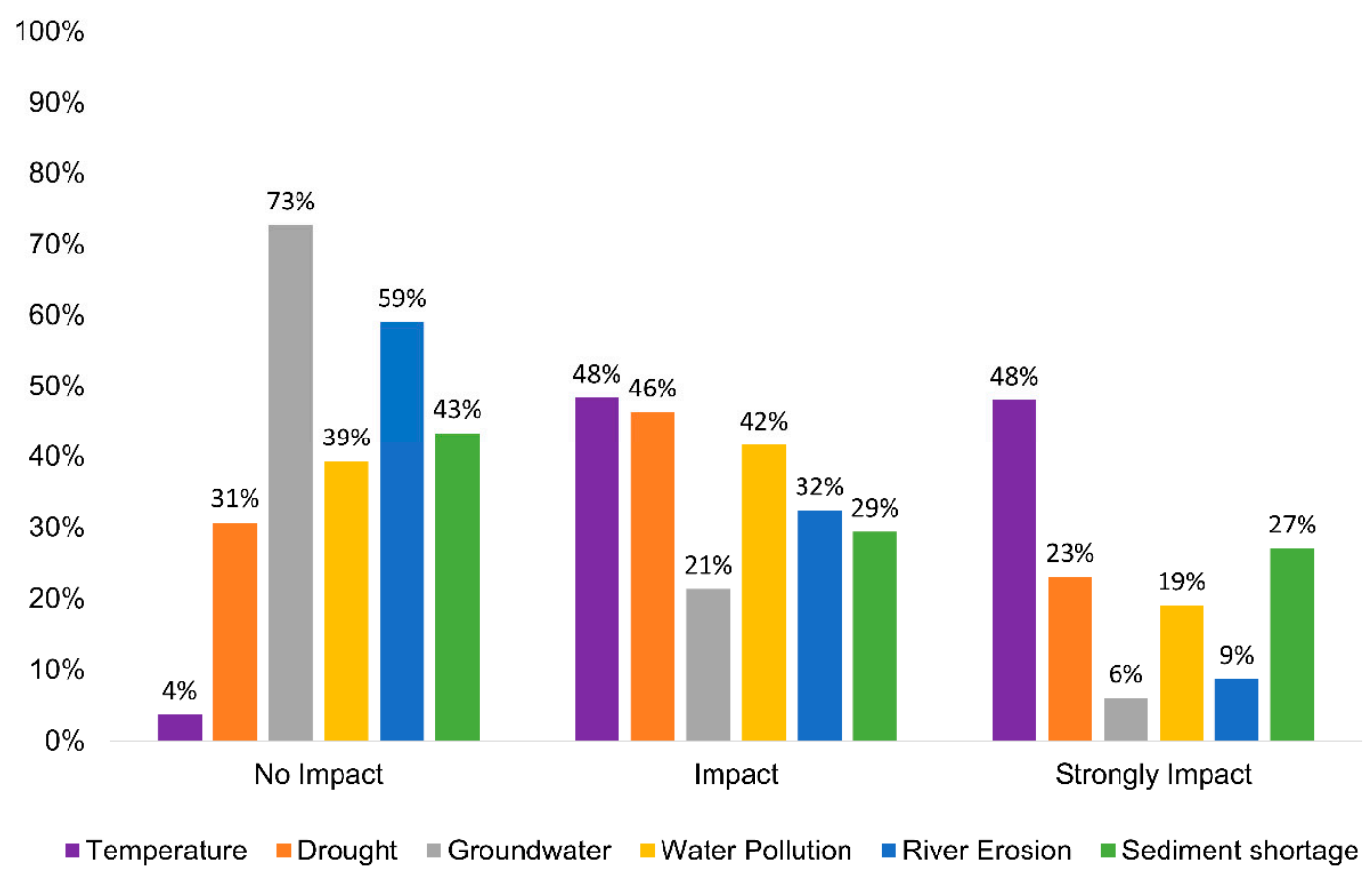

Figure 5. Farmers' perceptions of impacts of climate change and environmental pressure on their livelihoods in the past five years.

\subsection{Adaptation Options in Farming Practices}

Farmers had implemented various adaptation measures to cope with climate change and environmental pressure over the past five years (Figure 6). Some $73 \%$ of the farmers interviewed reported increasing production inputs, and $67 \%$ reported investing more labor time in production activities. Some $31 \%$ reported changing their method of rice production, $13 \%$ reported migrating to another region to earn a living, and 11\% reported a job change. In addition, some $10 \%$ of the farmers surveyed reported having to reduce the scale of production, and a small number of farmers $(1 \%)$ said workers had to move elsewhere to find a new means of livelihood during the past five years. Conversely, $9 \%$ of the farmers said they had increased their production scale to earn more income. None of the farmers reported having refrained farming activities in any of the past five years due to or to cope with climate change and environmental pressure.

\subsection{Limitations and Future Outlooks}

This study set out to better understand the perspectives of triple rice farmers. We conducted 300 interviews exploring an array of farm and farmer characteristics and vulnerabilities to the impacts of climate change and environmental pressure. To follow up this work, we would suggest that future research follows a similar approach but conducts more interviews with farmers from a wider geographic area, or even expands to a multi-country design, for example, across the entire upper VMD floodplains, including Cambodia. This would provide valuable comparative data, sharpen the findings 
and improve the methodology. In addition, we recommend interviewing scientists and officials as well as farmers, to provide more context on farmers' viewpoints and offer contrasting views that could be of value for policymaking. Last but not least, the low concern of farmers about the riverbank erosion could be appropriately re-assessed by future studies since this study may mostly interview the farmers who did not experience the erosion's impacts.

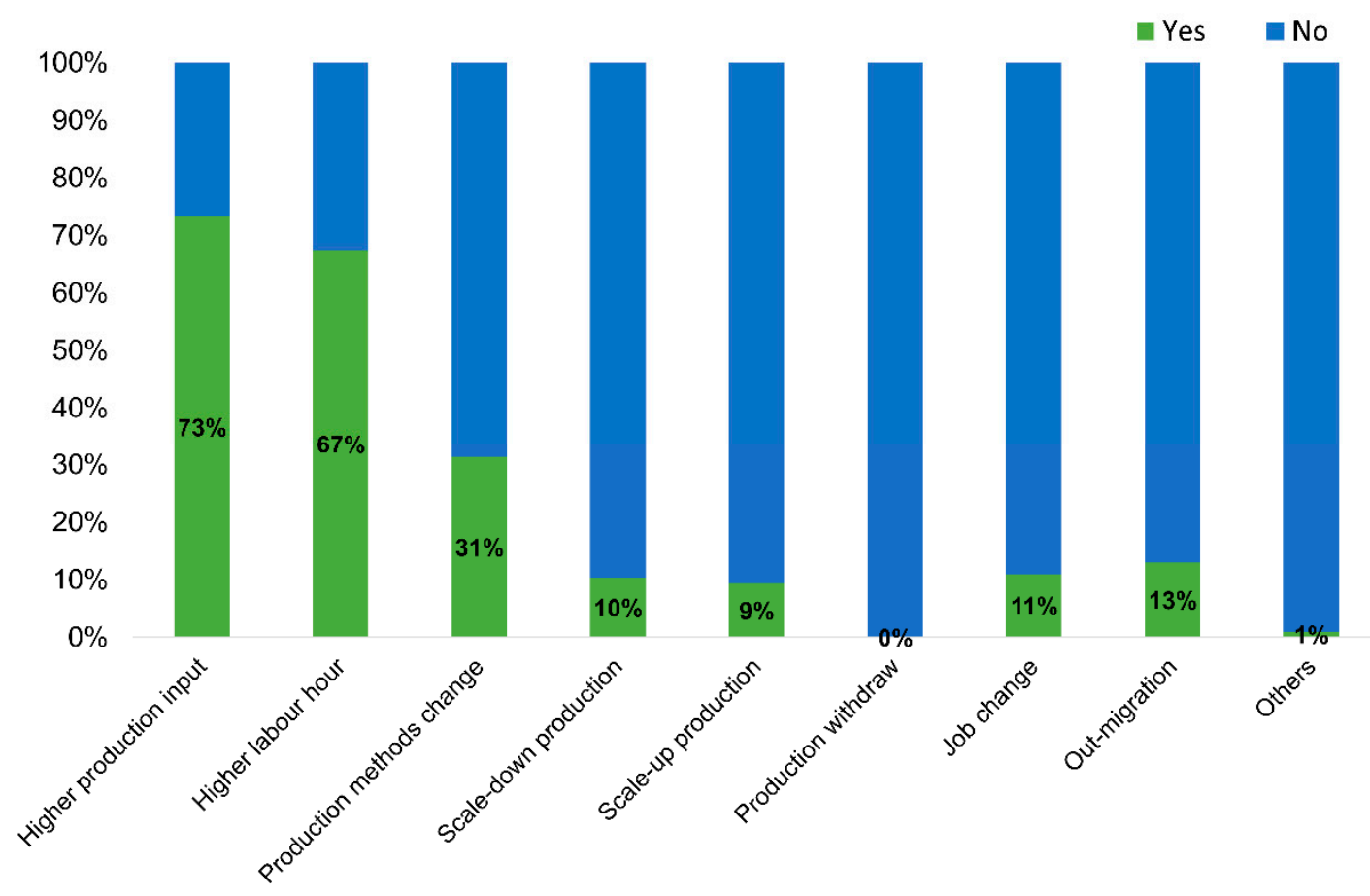

Figure 6. Adaption measures implemented by farmers to deal with climate change and environmental pressure.

\section{Conclusions}

This study provides evidence on the vulnerability of triple rice farmers on the upper floodplains of the Vietnam Mekong Delta (VMD). We combined the livelihood vulnerability index (LVI) approach with LVI-IPCC analysis to assess the sustainability of farmers' livelihoods in three districts of An Giang province under the impacts of climate change and environmental pressure. Most of the farmers we interviewed had observed changes in the key components studied over the past five years, and they had serious concerns regarding the continuation of such changes into the future. The findings of the current study suggest three main recommendations.

First, triple rice farmers should diversify their livelihoods in agricultural production. The triple rice monocrop is particularly susceptible to climate change and environmental pressure. We advise farmers to seek more diversified livelihood strategies in the short to long term. To this end, farmers will need to actively collaborate with scientists and local government officials to gather relevant knowledge and apply it in practice.

Second, our exposure indexes show that triple rice farmers are especially hard hit by the changing climate and environmental pressure. These farmers need urgent and dedicated support from government and the scientific establishment to not only increase their rice-production based income, but also to quickly adapt to the changes under way, for example, by introducing changes in cropping patterns, water saving technologies and improved rice varieties.

Finally, farmers' concerns regarding increasing temperatures, worsening water pollution and shortages of fertile sediment supply need to be taken seriously by all levels of government active in policymaking for the delta and its floodplains. Farmers have already put great effort into adaption 
measures to adjust to climate change and environmental pressure. However, the strategies within their grasp, particularly, increasing production inputs and investing more labor time, are not sustainable.

Author Contributions: D.D.T. developed the methodology and concept, performed data analysis and structured and wrote the first draft; C.N.X.Q. reviewed the literature, wrote the first draft of the manuscript, edited the text and managed correspondence; P.D.T., H.V.H., P.K.L., N.N.H.G., L.T.T.H. collected the data and contributed to the study concept; P.G.T. reviewed the state-of-the-art, commented on the content and structure of the manuscript. All authors have read and agreed to the published version of the manuscript.

Funding: This research received no external funding.

Acknowledgments: This research was funded by the Ministry of Science and Technology of Vietnam under grant KHCN-TNB.DT/14-19/C11.

Conflicts of Interest: The authors declare no conflict of interest.

Data Availability: Data used for this study are available from the corresponding author upon request. 


\section{Appendix A}

Table A1. Details of livelihood vulnerability index (LVI) analysis for the key components and subcomponents for the three surveyed districts of An Giang province.

\begin{tabular}{|c|c|c|c|c|c|c|c|c|}
\hline \multicolumn{2}{|c|}{ Major Components } & \multirow{2}{*}{ Sub-Components } & \multicolumn{2}{|c|}{ LVI Chau Phu } & \multicolumn{2}{|c|}{ LVI Tri Ton } & \multicolumn{2}{|c|}{ LVI Cho Moi } \\
\hline & & & Sub & Main & Sub & Main & Sub & Main \\
\hline \multirow{5}{*}{ 1. Human } & 1. Knowledge and skill & Fraction of household heads (Hhs) over 70 years old & 0.120 & 0.298 & 0.224 & 0.451 & 0.290 & 0.390 \\
\hline & & Fraction of Hhs just at primary school level & 0.475 & & 0.678 & & 0.489 & \\
\hline & 2. Experience and labor & Fraction of Hhs with agricultural production experience of less than five years & 0.058 & 0.179 & 0.122 & 0.211 & 0.056 & 0.188 \\
\hline & resources & Fraction of Hhs having only one laborer & 0.300 & & 0.300 & & 0.320 & \\
\hline & Overall $(1+2)$ & & & 0.238 & 0.000 & 0.331 & 0.000 & 0.289 \\
\hline \multirow{7}{*}{ 2. Social } & 3. Socio-demographic profile & Average number of dependent members in Hhs & 0.379 & 0.223 & 0.329 & 0.225 & 0.271 & 0.174 \\
\hline & & Fraction of female Hhs & 0.067 & & 0.122 & & 0.077 & \\
\hline & & Fraction of Hhs with insufficient connection with local authorities & 0.337 & 0.306 & 0.562 & 0.346 & 0.409 & 0.344 \\
\hline & 4. Social network & Fraction of Hhs with insufficient support from local authorities & 0.710 & & 0.633 & & 0.700 & \\
\hline & & Fraction of Hhs reporting weak linkages with agriculture extension units & 0.125 & & 0.100 & & 0.155 & \\
\hline & & Fraction of Hhs reporting weak linkages with traders & 0.050 & & 0.089 & & 0.111 & \\
\hline & Overall $(3+4)$ & & & 0.278 & 0.000 & 0.306 & 0.000 & 0.287 \\
\hline \multirow{8}{*}{ 3. Physical } & & Fraction of Hhs not having solid (fairly good) houses & 0.320 & 0.371 & 0.580 & 0.422 & 0.420 & 0.383 \\
\hline & & Fraction of Hhs without necessary living means (mobile phone, TV, bicycle, motorcycle) & 0.250 & & 0.240 & & 0.220 & \\
\hline & & Fraction of Hhs without good living means (air-conditioning, car, washing machine, car, electric generator) & 0.900 & & 0.930 & & 0.880 & \\
\hline & 5. Housing, land and & Fraction of Hhs with no machines and tractors for cultivation & 0.875 & & 0.789 & & 0.867 & \\
\hline & & Fraction of Hhs that rent lands for production & 0.108 & & 0.311 & & 0.222 & \\
\hline & & Fraction of ths that decreased the area of agricultural land over the past five years & 0.120 & & 0.071 & & 0.060 & \\
\hline & & Fraction of Hhs reporting that local transportation and electricity are worse & 0.025 & & 0.033 & & 0.011 & \\
\hline & Overall (5) & & & 0.371 & 0.000 & 0.422 & 0.000 & 0.383 \\
\hline \multirow{5}{*}{ 4. Finance } & & Fraction of Hhs with net income (from triple rice production) lower than 30 million VND/year (USD 1365/year) & 0.390 & 0.288 & 0.130 & 0.285 & 0.530 & 0.210 \\
\hline & & Fraction of Hhs having loans in the past five years & 0.300 & & 0.570 & & 0.230 & \\
\hline & 6. Finance and income & Fraction of Hhs that want to have loans in the future & 0.220 & & 0.330 & & 0.070 & \\
\hline & & Fraction of Hhs reporting their incomes are worse & 0.240 & & 0.110 & & 0.011 & \\
\hline & Overall (6) & & & 0.288 & 0.000 & 0.285 & 0.000 & 0.210 \\
\hline \multirow{3}{*}{ 5. Nature } & 7 Notul mo & Fraction of Hhs with small land $(<1.0 \mathrm{ha})$ have earned additional income from natural resources & 0.170 & 0.085 & 0.090 & 0.060 & 0.380 & 0.196 \\
\hline & 7. Natural resources & Fraction of Hhs does not have water from rivers/rainfall for production & 0.000 & & 0.030 & & 0.012 & \\
\hline & Overall (7) & & & 0.085 & 0.000 & 0.060 & 0.000 & 0.196 \\
\hline \multirow{6}{*}{$\begin{array}{l}\text { 6.Livelihood } \\
\text { strategy }\end{array}$} & & Fraction of Hhs does not diversify their crops (only rice) & 0.917 & 0.564 & 0.911 & 0.550 & 0.915 & 0.547 \\
\hline & & Fraction of ths that have not invested in more equipment during the past five years for climate change mitigation & 0.880 & & 0.840 & & 0.800 & \\
\hline & 8. Livelihood strategy & Fraction of Hhs that have not engaged in non-agricultural activities & 0.083 & & 0.089 & & 0.085 & \\
\hline & & Fraction of Hhs that experienced more impacts from natural disasters and climate change over the past five years & 0.120 & & 0.221 & & 0.095 & \\
\hline & & $\begin{array}{l}\text { Fraction of Hhs reporting that they will not expand lands for production } \\
\text { The }\end{array}$ & 0.820 & & 0.690 & & 0.840 & \\
\hline & Overall (8) & & & 0.564 & 0.000 & 0.550 & 0.000 & 0.547 \\
\hline
\end{tabular}


Table A1. Cont.

\begin{tabular}{|c|c|c|c|c|c|c|c|c|}
\hline \multirow{2}{*}{\multicolumn{2}{|c|}{ Major Components }} & \multirow{2}{*}{ Sub-Components } & \multicolumn{2}{|c|}{ LVI Chau Phu } & \multicolumn{2}{|c|}{ LVI Tri Ton } & \multicolumn{2}{|c|}{ LVI Cho Moi } \\
\hline & & & Sub & Main & Sub & Main & Sub & Mair \\
\hline \multirow{13}{*}{$\begin{array}{l}\text { 7. Natural disaster } \\
\text { and climate change }\end{array}$} & \multirow{6}{*}{ 9. Natural disaster } & Fraction of Hhs reporting that droughts have increased over the past five years & 0.300 & 0.168 & 0.470 & 0.235 & 0.460 & 0.300 \\
\hline & & Fraction of Hhs reporting that droughts will increase in the future & 0.510 & & 0.640 & & 0.420 & \\
\hline & & Fraction of Hhs reporting that groundwater shortages have increased over the past five years & 0.100 & & 0.060 & & 0.040 & \\
\hline & & Fraction of Hhs reporting that groundwater shortages will increase in the future & 0.030 & & 0.010 & & 0.070 & \\
\hline & & Fraction of Hhs reporting that river erosion has increased over the past five years & 0.030 & & 0.030 & & 0.270 & \\
\hline & & Fraction of Hhs reporting that river erosion will increase in the future & 0.040 & & 0.200 & & 0.540 & \\
\hline & \multirow{6}{*}{ 10. Climate change } & Fraction of Hhs reporting that temperatures have increased over the past five years & 0.950 & 0.643 & 0.830 & 0.630 & 0.860 & 0.622 \\
\hline & & Fraction of Hhs reporting that temperatures will increase in the future & 0.940 & & 0.960 & & 0.890 & \\
\hline & & Fraction of Hhs reporting that abnormal rainfall has increased over the past five years & 0.950 & & 0.830 & & 0.860 & \\
\hline & & Fraction of Hhs reporting that abnormal rainfalls will increase in the future & 0.940 & & 0.960 & & 0.890 & \\
\hline & & Fraction of Hhs reporting that sediment loads have increased over the past five years & 0.040 & & 0.110 & & 0.070 & \\
\hline & & Fraction of Hhs reporting that sediment loads will increase in the future & 0.040 & & 0.090 & & 0.160 & \\
\hline & \multicolumn{2}{|l|}{ Overall $(9+10)$} & 0.406 & & 0.433 & & 0.461 & \\
\hline \multicolumn{2}{|c|}{$\mathrm{LVI}=$} & & 0.356 & & 0.383 & & 0.376 & \\
\hline
\end{tabular}




\section{References}

1. Wei, B.; Su, G.; Qi, W.; Sun, L. The Livelihood Vulnerability of Rural Households in Earthquake-Stricken Areas-A Case Study of Ning'er, Yunnan Province. Sustainability 2016, 8, 566. [CrossRef]

2. Wei, B.; Su, G.; Li, Y.; Ma, Y. Livelihood Strategies of Rural Households in Ning'er Earthquake-Stricken Areas, Yunnan Province, China. Sustainability 2019, 11, 566. [CrossRef]

3. Tran, D.D.; Huu, L.H.; Hoang, L.P.; Pham, T.D.; Nguyen, A.H. Sustainability of rice-based livelihoods in the upper floodplains of Vietnamese Mekong Delta: Prospects and challenges. Agric. Water Manag. 2021, 243, 106495. [CrossRef]

4. Tran, D.D.; van Halsema, G.; Hellegers, P.J.G.J.; Hoang, L.P.; Ludwig, F. Long-term sustainability of the Vietnamese Mekong Delta in question: An economic assessment of water management alternatives. Agric. Water Manag. 2019, 223, 105703. [CrossRef]

5. Tran, D.D.; van Halsema, G.; Hellegers, P.J.G.J.; Ludwig, F.; Wyatt, A. Questioning triple rice intensification on the Vietnamese mekong delta floodplains: An environmental and economic analysis of current land-use trends and alternatives. J. Environ. Manag. 2018, 217, 429-441. [CrossRef] [PubMed]

6. Tran, D.D.; Weger, J. Barriers to Implementing Irrigation and Drainage Policies in An Giang Province, Mekong Delta, Vietnam. Irrig. Drain. 2018, 67, 81-95. [CrossRef]

7. Tran, D.D.; van Halsema, G.; Hellegers, P.J.G.J.; Ludwig, F.; Seijger, C. Stakeholders' assessment of dike-protected and flood-based alternatives from a sustainable livelihood perspective in An Giang Province, Mekong Delta, Vietnam. Agric. Water Manag. 2018, 206, 187-199. [CrossRef]

8. Pandey, R.; Jha, S.K.; Alatalo, J.M.; Archie, K.M.; Gupta, A.K. Sustainable livelihood framework-based indicators for assessing climate change vulnerability and adaptation for Himalayan communities. Ecol. Indic. 2017, 79, 338-346. [CrossRef]

9. Laila, F. Assessment on Social Vulnerabilities to Climate Change-A Study on South-Western Coastal Region of Bangladesh, Uppsala University, Department of Earth Sciences; Department of Earth Sciences: Villavägen Uppsala, Sweden, 2013.

10. Chapman, A.; Darby, S. Evaluating sustainable adaptation strategies for vulnerable mega-deltas using system dynamics modelling: Rice agriculture in the Mekong Delta's An Giang Province, Vietnam. Sci. Total Environ. 2016, 559, 326-338. [CrossRef]

11. Nguyen, H.Q.; Tran, D.D.; Luan, P.D.M.H.; Ho, L.H.; Loan, V.T.K.; Anh Ngoc, P.T.; Quang, N.D.; Wyatt, A.; Sea, W. Socio-ecological resilience of mangrove-shrimp models under various threats exacerbated from salinity intrusion in coastal area of the Vietnamese Mekong Delta. Int. J. Sustain. Dev. World Ecol. 2020, 2020, 1731859. [CrossRef]

12. Nguyen, L.A.; Pham, T.B.V.; Bosma, R.; Verreth, J.; Leemans, R.; De Silva, S.; Lansink, A.O. Impact of Climate Change on the Technical Efficiency of Striped Catfish, Pangasianodon hypophthalmus, Farming in the Mekong Delta, Vietnam. J. World Aquac. Soc. 2018, 49, 570-581. [CrossRef]

13. Salik, K.M.; Jahangir, S.; ul Hasson, S. Climate change vulnerability and adaptation options for the coastal communities of Pakistan. Ocean Coast. Manag. 2015, 112, 61-73. [CrossRef]

14. Roel, H.B.; Henk, M.J.U.; Johan, A.J.V.; Leontine, L.; Nam, C.Q. Agriculture Diversification in the Mekong Delta: Farmers' Motives and Contributions to Livelihoods. Asian J. Agric. Dev. 2006, 49-66.

15. Hahn, M.B.; Riederer, A.M.; Foster, S.O. The Livelihood Vulnerability Index: A pragmatic approach to assessing risks from climate variability and change-A case study in Mozambique. Glob. Environ. Chang. 2009, 19, 74-88. [CrossRef]

16. Zhao, Y.; Fan, J.; Liang, B.; Zhang, L. Evaluation of Sustainable Livelihoods in the Context of Disaster Vulnerability: A Case Study of Shenzha County in Tibet, China. Sustainability 2019, 11, 2874. [CrossRef]

17. Su, Z.; Aaron, R.J.; Guan, Y.; Wang, H. Sustainable Livelihood Capital and Strategy in Rural Tourism Households: A Seasonality Perspective. Sustainability 2019, 11, 4833. [CrossRef]

18. Liu, Z.; Chen, Q.; Xie, H. Influence of the Farmer's Livelihood Assets on Livelihood Strategies in the Western Mountainous Area, China. Sustainability 2018, 10, 875. [CrossRef]

19. Van Manh, N.; Dung, N.V.; Hung, N.N.; Kummu, M.; Merz, B.; Apel, H. Future sediment dynamics in the Mekong Delta floodplains: Impacts of hydropower development, climate change and sea level rise. Glob. Planet. Chang. 2015, 127, 22-33. [CrossRef] 
20. Quang, D.; Balica, S.; Popescu, I.; Jonoski, A. Climate change impact on flood hazard, vulnerability and risk of the Long Xuyen Quadrangle in the Mekong Delta. Int. J. River Basin Manag. 2012, 10, 103-120.

21. Triet, N.V.K.; Dung, N.V.; Hoang, L.P.; Le Duy, N.; Tran, D.D.; Anh, T.T.; Kummu, M.; Merz, B.; Apel, H. Future projections of flood dynamics in the Vietnamese Mekong Delta. Sci. Total Environ. 2020, 742, 140596. [CrossRef]

22. Ministry of Natural Resources and Environment of Vietnam. Scenarios of Climate Change and Sea Level Rise in Vietnam (In Vietnamese: Kịch Bản Biến Đổi Khí Hậu Và Nước Biển Dâng Cho Việt Nam); Vietnam Publishing House of Natural Resources, Environment and Cartography: Hanoi, Vietnam, 2016.

23. Tran, D.D.; Van Halsema, G.; Hellegers, P.J.; Tran, T.Q.; Ludwig, F. Assessing impacts of dike construction on the flood dynamics in the Mekong Delta. Hydrol. Earth Syst. Sci. 2018, 22, 1875-1896. [CrossRef]

24. Hoang, L.P.; van Vliet, M.T.H.; Kummu, M.; Lauri, H.; Koponen, J.; Supit, I.; Leemans, R.; Kabat, P.; Ludwig, F. The Mekong's future flows under multiple drivers: How climate change, hydropower developments and irrigation expansions drive hydrological changes. Sci. Total Environ. 2019, 649, 601-609. [CrossRef] [PubMed]

25. Kondolf, G.M.; Schmitt, R.J.P.; Carling, P.; Darby, S.; Arias, M.; Bizzi, S.; Castelletti, A.; Cochrane, T.A.; Gibson, S.; Kummu, M.; et al. Changing sediment budget of the Mekong: Cumulative threats and management strategies for a large river basin. Sci. Total Environ. 2018, 625, 114-134. [CrossRef] [PubMed]

26. Arias, M.; Piman, T.; Lauri, H.; Cochrane, T.; Kummu, M. Dams on Mekong tributaries as significant contributors of hydrological alterations to the Tonle Sap Floodplain in Cambodia. Hydrol. Earth Syst. Sci. 2014, 18, 5303-5315. [CrossRef]

27. Kuenzer, C.; Campbell, I.; Roch, M.; Leinenkugel, P.; Tuan, V.Q.; Dech, S. Understanding the impact of hydropower developments in the context of upstream-downstream relations in the Mekong river basin. Sustain. Sci. 2013, 8, 565-584. [CrossRef]

28. Park, E.; Ho, H.L.; Tran, D.D.; Yang, X.; Alcantara, E.; Merino, E.; Son, V.H. Dramatic decrease of flood frequency in the Mekong Delta due to river-bed mining and dyke construction. Sci. Total Environ. 2020, 723, 138066. [CrossRef]

29. Hung, N.N.; Delgado, J.M.; Güntner, A.; Merz, B.; Bárdossy, A.; Apel, H. Sedimentation in the floodplains of the Mekong Delta, Vietnam Part II: Deposition and erosion. Hydrol. Process. 2014, 28, 3145-3160. [CrossRef]

30. Lu, X.X.; Siew, R.Y. Water discharge and sediment flux changes over the past decades in the Lower Mekong River: Possible impacts of the Chinese dams. Hydrol. Earth Syst. Sci. 2006, 10, 181-195. [CrossRef]

31. Fredrik, F. Impacts of Dams on Lowland Agriculture in the Mekong River Catchment; Lund University: Lund, Sweden, 2011.

32. Tong, Y.D. Rice Intensive Cropping and Balanced Cropping in the Mekong Delta, Vietnam-Economic and Ecological Considerations. Ecol. Econ. 2017, 132, 205-212. [CrossRef]

33. Berg, H.; Ekman Söderholm, A.; Söderström, A.-S.; Tam, N.T. Recognizing wetland ecosystem services for sustainable rice farming in the Mekong Delta, Vietnam. Sustain. Sci. 2017, 12, 137-154. [CrossRef]

34. Marchand, M.; Pham Quang, D.; Le, T. Mekong Delta: Living with water, but for how long? Built Environ. 2014, 40, 230-243. [CrossRef]

35. Le, T.N.; Bregt, A.K.; van Halsema, G.E.; Hellegers, P.J.; Nguyen, L.D. Interplay between land-use dynamics and changes in hydrological regime in the Vietnamese Mekong Delta. Land Use Policy 2018, 73, 269-280. [CrossRef]

36. Dung, D.T.; Gerardo, V.H.; Petra, J.G.J.H.; Ludwig, F.; Chris, S. Stakeholders assessment of alternative flood-based farming systems from a sustainable livelihood perspective in An Giang province. Agric. Water Manag. 2018, 206, 187-199.

37. An Giang Statistical Office. Statistical Yearbook (In Vietnamese: Niên Giám Thống kê); House, S.O., Ed.; An Giang Statistical Office Publishing: An Giang, Vietnam, 2019.

38. Howie, C. Co-Operation and Contestation: Farmer-State Relations in Agricultural Transformation, An Giang Province, Vietnam; University of London: London, UK, 2011.

39. Departement for International Development. Sustainable Livelihoods Guidance Sheets Framework Introduction Vulnerability Transforming. Context 1999, 26. [CrossRef]

40. SIWRR. Detailed Water Resources Planning for Agricultural Production in An Giang Province until 2020; SIWRP: Ho Chi Minh City, Vietnam, 2012.

41. Biggs, D. Quagmire-Nation-Building and Nature in the Mekocng Delta; University of Washington Press: Seattle, WA, USA, 2010; ISBN 978-0-295-99067-5. 
42. General Statistics Office of An Giang Province. Niên Giám Thống kê tỉnh An Giang; Thanh Nien Publishing Company: An Giang, Vietnam, 2016.

43. Li, H.; Nijkamp, P.; Xie, X.; Liu, J. A New Livelihood Sustainability Index for Rural Revitalization Assessment-A Modelling Study on Smart Tourism Specialization in China. Sustainability 2020, 12, 3148. [CrossRef]

44. Tjoe, Y. Measuring the livelihood vulnerability index of a dry region in Indonesia: A case study of three subsistence communities in West Timor. World J. Sci. Technol. Sustain. Dev. 2016, 13, 250-274. [CrossRef]

45. Adu, D.T.; Kuwornu, J.K.M.; Anim-Somuah, H.; Sasaki, N. Application of livelihood vulnerability index in assessing smallholder maize farming households' vulnerability to climate change in Brong-Ahafo region of Ghana. Kasetsart J. Soc. Sci. 2018, 39, 22-32. [CrossRef]

46. Nguyen, D.L.; Grote, U.; Nguyen, T.T. Migration, crop production and non-farm labor diversification in rural Vietnam. Econ. Anal. Policy 2019, 63, 175-187. [CrossRef]

47. Alam, M.J.; Humphreys, E.; Sarkar, M.A.R. Sudhir-Yadav Intensification and diversification increase land and water productivity and profitability of rice-based cropping systems on the High Ganges River Floodplain of Bangladesh. F. Crop. Res. 2017, 209, 10-26. [CrossRef]

48. Niehof, A. The significance of diversification for rural livelihood systems. Food Policy 2004, 29, 321-338. [CrossRef]

49. UNDRMT. Vietnam Consolidated Report on Drought and Saltwater Intrusion Reporting Period: October 2015-March 2016; Disaster Risk Management Team (UNDRMT): Ha Noi, Vietnam, 2016.

50. Dang, H.V.; Tran, D.D.; Pham, B.T.; Khoi, N.D.; Tran, H.P.; Nguyen, T.N. Exploring Freshwater Regimes and Impact Factors in the Coastal Estuaries of the Vietnamese Mekong Delta. Water 2019, 11, 782. [CrossRef]

Publisher's Note: MDPI stays neutral with regard to jurisdictional claims in published maps and institutional affiliations. 